\title{
Study on the Relationship between Social Studies Course Self-Efficacy and Motivation Levels of Secondary School Students
}

\author{
Gökçe Kılıçoğlu \\ Gazi College of Education, Gazi University, Turkey
}

Copyright $(2018$ by authors, all rights reserved. Authors agree that this article remains permanently open access under the terms of the Creative Commons Attribution License 4.0 International License

\begin{abstract}
The purpose of this study is to examine secondary school students' social studies course self -efficacy and social studies course motivation (intrinsic motivation, heeding, extrinsic motivation) levels. Study sample is composed of 3057 th class secondary school students. In the study, data was collected using relational survey model and "Social Studies Course Self-Efficacy Scale" and "Social Studies Course Motivation Scale" were applied to the students. In the study, firstly Pearson correlation coefficients were calculated and the relationships between the variables were examined, then, multiple linear regression analysis was performed with intrinsic motivation, extrinsic motivation, heeding and academic achievement variables. The data obtained in the study shows that intrinsic motivation, extrinsic motivation and academic achievement variables predict students' social studies self-efficacy levels and explain $64 \%$ of self-efficacy. On the other hand, it has been determined that heeding dimension of the motivation is not a significant predictor of self-efficacy.
\end{abstract}

Keywords Self-efficacy, Motivation, Social Studies Course

\section{Introduction}

There are many intrinsic and extrinsic factors that determine behaviors that individuals display in their daily lives. These factors may not always be controlled. Unlike everyday life, in education, in order to achieve desired behavior it is important to control and effectively use the factors that cause the individual to gain and maintain the behavior. It is seen that while some students seem willing to produce solutions to a lesson, a topic or an encountered problem, some of them are reluctant or not eager enough. This difference among students is mainly caused by fomentation [1], in other words motivation.

The motivation [2] which means fomentation and incentive in Turkish is defined by Deci and Ryan [3] as acting to do something and it is defined by Pintrich and Schunk [4] as a process where the action starts directly to the purpose and the action is maintained.

Within the framework of self-determination theory, Deci and Ryan [5] classify motivation as intrinsic motivation, extrinsic motivation, and lack of motivation. İntrinsic motivation is defined as the intention and interest of an individual to do something, and the extrinsic motivation is defined as focusing on the outcome of something, while [3] lack of motivation is expressed as a lack of interest, desire and effort to do something [5].

One of the important compounds in the motivation that it has got two main duties such as starting and sustaining a behavior is whether an individual attaches importance to a situation, namely he/she minds it in terms of the individual's learning [6,7]. When the students accept the concepts and activities as the important and meaningful for themselves, they will be eager in the active participation in the duties to be given and activities to be made in the classroom. However, the permanent learning will not occur and the students will make the memorization when they think that the subjects to be learnt are not necessary and important. The learning goal and value have got importance in the students as they are motivated to make the scientific knowledge [8].

No doubt the motivation has an important place in learning process. Students getting motivated during the learning process are more likely to try to solve the problem than to withdraw from any problem they encounter [9]. In order for students to be actively involved in the learning process, they must be motivated to be a part of this process, that is, they need to be motivated to learn [10]. The incentive effect of motivation contributes significantly to the learning process and helps to control the learning process in terms of learners. From here it can be said that 
motivation is not only important for learning but also it is not sufficient by itself.

As social studies course is a verbal course, there is more responsibility for teachers in ensuring the attention and motivation of the students. In social sciences course, monotone presentation by teachers without bringing different views to the topic makes the student passive and it cannot go beyond the transfer of knowledge for the student [11]. This leads students to memorisation, and as a result, the interest, desire and motivation of students for the lesson decreases. For this reason, it is necessary to make the learning process more efficient in order to involve the students in the course activities, to make them study and to motivate them.

Motivating students for courses and learning activities is the most challenging task for both parents and teachers. In order to achieve this, it is very important to determine and control the factors affecting the motivation of students and to make the learning and teaching process more effective and efficient [12]. Garcia [13] mentions existence of elements such as perception capacity, effort, goal orientation, focusing on work, self-efficacy and self-evaluation at the top of the factors affecting motivation. Bandura [14], on the other hand, expresses that self-efficacy belief, which is one of these factors, does not only support the resistance and effort shown by individuals against any situation, but it also supports motivation. Self-efficacy is the belief of an individual in his/her capacity to organize an activity required to demonstrate a certain performance and to complete it successfully. Self-efficacy belief affects people's thoughts, feelings, direction of their actions and the nature of the methods they use to motivate themselves, and as a consequence, it determines the level of enthusiasm, assertiveness and determination that people will put forth $[15,16]$. When evaluated in terms of learners, it can be said that students with high self-efficacy beliefs are more involved in the learning process and make more effort in learning [17].

Social studies self-efficacy levels are one of the most important factors affecting the achievement of students in the lesson. Therefore, in order for the students to be able to reach the gains related to the skills and values determined in the social studies program, it would be beneficial to prepare the education and training activities in the social studies course taking into consideration the self-efficacy levels of the students [18].

In revealing students' knowledge and skills, it is important to identify beliefs such as motivation and self-efficacy. Because there is a mutual relationship between self-efficacy and motivation. The perception of progression when acquiring a skill or knowledge influences individual's self-efficacy and motivation orientation. When the literature is examined, it is seen that there is a limited number of studies on the relation between social studies course motivation and social studies course self-efficacy of secondary school students [19, 20]. From this point of view, this study focuses on the self-efficacy and motivation structures that are considered an important factor on success levels of students. It is aimed to contribute to the literature by examining the relationship between the students' social studies course self-efficacy and social studies course motivation levels.

\section{Methods}

\subsection{Purpose of the Study}

The purpose of this study is to examine the relationship between social studies course self-efficacy and social studies course motivation (intrinsic motivation, heeding, extrinsic motivation) of secondary school students. Furthermore, in the study it has been tried to found out how much the intrinsic motivation, extrinsic motivation, heeding and academic achievement predict students' self-efficacy levels.

\subsection{Method}

In the study, data was collected using survey model. In the study, firstly Pearson correlation coefficients were calculated and the relationships between the variables were examined. Then, multiple linear regression analysis was performed with intrinsic motivation, heeding and extrinsic motivation subdimensions of social studies course motivation in order to predict students' social studies self-efficacy levels.

\subsection{Study Group}

The study was conducted in 2017-2018 academic year. The students were informed of the purpose of the study and the measurement tools. It was stated that the personal information of students would be kept confidential by the researchers. It is paid attention that the schools and classes where the sample is selected show similar features. The sample of the study is composed of 305 secondary school students who study in 5 secondary schools located in the center of Trabzon province.

\subsection{Demografic Data Form}

In this study, gender and social studies course grade of the previous term were asked to the study group. Frequency distribution of gender and academic achievement of students' social studies course is shown in table 1 .

Table 1. Demographic information of study group

\begin{tabular}{|c|c|c|c|}
\hline \multicolumn{2}{|c|}{} & Frequency $(f)$ & Percentage (\%) \\
\hline \multirow{2}{*}{ Gender } & Women & 159 & 52,1 \\
\cline { 2 - 4 } & Men & 146 & 47,9 \\
\hline \multirow{2}{*}{ Academic } & 3 & 22 & 7,2 \\
\cline { 2 - 4 } Achievement & 4 & 95 & 31,1 \\
\cline { 2 - 4 } & 5 & 188 & 61,6 \\
\hline
\end{tabular}




\subsection{Measures}

\section{Social Studies Course Self-Efficacy Scale}

In order to determine students' social studies course self-efficacy levels, "Social Studies Course Self-Efficacy Scale" developed by Doğan, İlhan Beyaztaş and Koçak [18] was used.

The scale is a one-dimensional scale factor loads of which vary between 0.46 and 0.75 and is composed of 25 articles. The intrinsic consistency coefficient (Cronbach Alpha) of the scale was calculated as 0.95 . This value is interpreted as an evidence that the level of intrinsic consistency of articles is very high. Confirmatory factor analysis was done for construct validity of the scale and it was found that regression values standardized with total scale scores of articles vary between 0,42 and 0,84 , and that all coefficients were found statistically significant at the level of 0,01 .

Validity and reliability values of the scale for this study were recalculated. Confirmatory factor analysis was performed using the Lisrell 8.8 [21] program for this and the reliability value was calculated. Result of the conducted DFA showed that the model well suited the data. $\left(\chi_{(14)}^{2}=\right.$ $28.49, \mathrm{p}<.05, \chi^{2} / \mathrm{df}=2.03$, RMSEA $=0.068, \mathrm{CFI}=.97$, $\mathrm{IFI}=.97 ; \mathrm{GFI}=.97 ; \mathrm{NFI}=.95 ; \mathrm{NNFI}=.96$ ). In addition, the reliability coefficient of the scale was determined as Cronbach alpha .77 .

Table 2 includes sample articles of self-efficacy scale in social studies course.

Table 2. Sample articles of self-efficacy scale in social studies course

\begin{tabular}{|c|}
\hline I think I'm not talented in social studies course. \\
\hline I can do research about a subject related to social studies course. \\
\hline I can overcome any subject related to social studies course. \\
\hline I can take advantage of what I've learned in social studies course \\
while evaluating daily events. \\
\hline
\end{tabular}

\section{Motivation Scale of Social Studies Course}

"Social Studies Course Motivation Scale" developed by Gömleksiz and Kan [22] was used to determine motivation levels of the students in social studies course. Factor analysis was done to reveal the construct validity of the motivation scale. The 23-article scale is a three-factor scale factor load of which vary between .743 and .457 . When the subdimensions of the scale were taken into consideration, it was seen that the first factor included articles which reveal intrinsic motivation for social studies course. There are 9 items in this section. The second part of the scale is called the "heeding" sub-dimension. The scale includes 8 articles related to the heeding dimension. It was seen that the third part is mostly composed of the articles giving extrinsic motivation related to social studies course. This subdimension of the scale is represented by 6 articles. In the reliability calculation done for sub-dimensions, intrinsic motivation is determined as 802; extrinsic motivation as .745 and heeding as .826. KMO value of the scale is .890; The Bartlett test result is 4.395. The total Cronbach Alpha coefficient of the scale is .792, and the total variance explained by the scale has been calculated as $41.085 \%$.

The validity and reliability values of the scale recalculated for this study are as follows: The DFA result showed that data of the model was at the acceptable level $\left(\chi^{2}(222)=512.66, p<.01, \chi^{2} / d f=2.30\right.$, RMSEA $=0.066$, $\mathrm{SRMR}=.087, \mathrm{CFI}=.93, \mathrm{IFI}=.93$, NNFI $=.92)$. In addition, the reliability coefficient of the scale was determined as Cronbach alpha .79 .

Table 3 includes sample articles of the motivation scale for social studies course.

Table 3. Sample articles of motivation scale for social studies course

\begin{tabular}{|c|}
\hline Intrinsic Motivation \\
\hline I study with pleasure to be successful in social studies course. \\
\hline I do research to learn what I wonder about social studies course. \\
\hline I follow carefully social studies course to learn new things. \\
\hline Extrinsic Motivation \\
\hline $\begin{array}{c}\text { I study for social studies course in order that my teacher appreciates } \\
\text { me. }\end{array}$ \\
\hline I want to be successful in social studies course in order to be a \\
popular student. \\
\hline I study for social studies course in order to win my teacher's favor. \\
\hline Heeding \\
\hline I don't make effort to get high marks in social studies course. \\
\hline I don't be sad if I fail in social studies course. \\
\hline I don't care about studying for social studies course. \\
\hline
\end{tabular}

\section{Findings}

\subsection{Descriptive Statistics and Correlations}

The average and standard deviation values of subdimensions of social studies course self-efficacy scale and social studies course motivation scale (intrinsic motivation, extrinsic motivation, heeding) used in the study are shown in table 4.

Table 4. Descriptive statistics

\begin{tabular}{|c|c|c|}
\hline Variables & Avarage Value & SD \\
\hline 1. Self-Efficacy & 4.00 & .61 \\
\hline 2. Intrinsic Motivation & 4.20 & .55 \\
\hline 3. Heeding & 4.46 & .42 \\
\hline 4. Extrinsic Motivation & 3.30 & 1.04 \\
\hline
\end{tabular}

When table 4 is examined, it is understood that when we look at the social studies course self-efficacy levels of secondary school students, mid point of the 5 -point likert scale is above (3) $(X=4.00)$, i.e students have a good level of self-efficacy. When the subdimensions of social studies course motivation scale is considered, when evaluated 
according to the 5 -point likert scale, it is understood that they have a high level of average considering subdimensions of intrinsic motivation $(X=4.20)$, and heeding ( $\mathrm{X}=4.46)$ and they have an average level of average considering the subdimension of extrinsic motivation $(X=3,30)$.

Within the study, Pearson correlation coefficients were calculated to examine the relationships among variables, and values are shown in table 5 .

Table 5. Correlations

\begin{tabular}{|c|c|c|c|}
\hline Variables & 2 & 3 & 4 \\
\hline 1. Self-Efficacy & $.689^{* *}$ & $.334^{* *}$ & $.347^{* *}$ \\
\hline 2.Intrinsic Motivation & & $.381^{* *}$ & $.449^{* *}$ \\
\hline 3. Heeding & & & -.027 \\
\hline 4. Extrinsic Motivation & & & \\
\hline
\end{tabular}

$* * \mathrm{p}<.01$
When the correlation coefficients were examined in the table 5, the highest correlation was found to be moderate ( $\mathrm{r}$ $=.689, \mathrm{p}<0.01)$ between self-efficacy and intrinsic motivation which is one of the sub-dimensions of motivation scale; and it was determined that the correlation between subdimensions of self- efficacy, heeding $(r=.334$, $\mathrm{p}<.01)$ and extrinsic motivation $(\mathrm{r}=.347, \mathrm{p}<.01)$ is at the average level.

In the study, multiple linear regression analysis was conducted using the SPSS 20 program to determine the variables that predict the social studies course self-efficacy of students. Within the analysis, social studies course self-efficacy was taken as dependent variable; subdimensions (intrinsic motivation, extrinsic motivation, heeding) of academic achievement were taken as independent variables. The results of the analysis are shown in table 6.

Table 6. Multiple regression analysis of variables predicting social studies course self-efficacy

\begin{tabular}{|c|c|c|c|c|c|c|c|}
\hline & $\mathrm{B}$ & $\begin{array}{c}\text { Std. } \\
\text { Error }\end{array}$ & $\beta$ & $\mathrm{T}$ & $\mathrm{p}$ & $\begin{array}{c}\text { Bilateral } \\
\mathrm{r}\end{array}$ & $\begin{array}{c}\text { Partial } \\
\mathrm{r}\end{array}$ \\
\hline Variable &,- 025 &, 182 & - &,- 138 &, 890 & - & - \\
\hline Fixed &, 222 &, 031 &, $253^{*}$ & 7,262 &, 000 &, 457 &, 353 \\
\hline Intrinsic Motivation &, 698 &, 045 &, $659 *$ & 15,516 &, 000 &, 769 &, 628 \\
\hline Heeding &,- 024 &, 043 &,- 021 &,- 568 &, 570 &, 405 &,- 030 \\
\hline Extrinsic Motivation &, 057 &, 026 &, $080^{*}$ & 2,190 &, 029 &, 374 &, 113 \\
\hline
\end{tabular}

$\mathrm{R}=0,80 \quad \mathrm{R}^{2}=0,64$

$\mathrm{F}_{(4-370)}=167,580 * \mathrm{p}<.01$

The regression analysis result of predicting self-efficacy of secondary school students which is related to intrinsic motivation, extrinsic motivation, heeding and academic achievement variables is given in table 6 .

When bilateral and partial correlations between the predictor variables and the dependent variable are examined, there is a positive strong correlation $(r=0.77)$ between the self-efficacy score and the intrinsic motivation. However, when other variables were checked, the correlation between the two variables was calculated as $r=0,63$. There is a positive moderate correlation $(\mathrm{r}=0.40)$ between the heeding score and the self-efficacy score. However, when other variables were checked, the correlation between the two variables was calculated as $r=-0.03$. There is a positive moderate correlation $(\mathrm{r}=0.37)$ between the extrinsic motivation score and the self-efficacy scores of the students. However, when other variables are checked, thecorrelation between the two variables is again seen to be positive, but at a weak level $r=$ $-0,11$. There is a positive moderate correlation $(r=-0,46)$ between the academic achievement score and self-efficacy scores of the students. However, when the variables are checked, the correlation between the two variables have been calculated as $r=-0,35$.

Intrinsic motivation, extrinsic motivation, academic achievement scores have a high and meaningful relationship with self-efficacy scores $\left[R=0,80 ; \mathrm{R}^{2}=0,64, \mathrm{p}<, 05\right]$. Three variables together explain $64 \%$ of the total variance.

According to the standardized regression coefficient $(\beta)$, the relative importance order of the predictive variables over self-efficacy is intrinsic motivation, academic achievement and extrinsic motivation score. When the t-test results of the significance of the regression coefficients are examined, it is seen that intrinsic motivation, academic achievement and extrinsic motivation variables are significant predictors of self-efficacy perceptions. The heeding variable does not have any significant effect. 


\section{Conclusions}

In this study, the relationship between the social studies course self-efficacy and motivations of the secondary school students was examined. Intrinsic motivation, extrinsic motivation and heeding, which are sub-dimensions of motivation, are considered as predictive variables, and social studies academic achievement has also been included in the multiple regression analysis to clarify the relationship between these variables and self-efficacy and to see their effect.

When we look at the social studies course self-efficacy level of the secondary school students as a result of the study, it is understood that students have a high level of self-efficacy and when the subdimensions of the social studies course motivation scale is considered, it is understood that they have a high level of self- efficacy within subdimensions of intrinsic motivation and heeding and it is average within subdimensions of extrinsic motivation. In his study, where Özkal [20] achieved parallel results with this study, he found out that the intrinsic motivations of the students for social studies course were high and their extrinsic motivations were moderate. From this, it can be said that students are motivated more through intrinsic factors rather than extrinsic factors.

Students' expectations about the task they will perform, their desire and skill to complete this task successfully, and their self-efficacy related to their success affect their motivations [23]. Self-efficacy has a great and positive effect on motivation $[24,25,26]$. It is expected that the student with high self-efficacy for a lesson should have academic achievement and motivation in learning the lesson $[14,27]$. When the correlation coefficients of the students were examined according to the results obtained from the study, it was found that the highest correlation is in the intrinsic motivation from the subdimensions of self-efficacy and motivation scale; self-efficacy and motivation scale, and extrinsic motivation sub-dimensions and self-efficacy relationship were moderate $[14,28,29,30,31]$. Considering the studies carried out in this respect, it is stated that the relationship between self-efficacy and intrinsic motivation is positive. It can be said that the intrinsic motivation of students with high self-efficacy beliefs is also high considering that self-efficacy and intrinsic motivation relation is so strong. Learners with high self-efficacy are more intrinsicly enthusiastic due to their high belief in themselves and their learning. This makes them more successful in learning.

Another outcome of the study shows that intrinsic motivation, extrinsic motivation and academic achievement predict students' self-efficacy levels significantly. As a predictor of self-efficacy level, intrinsic motivation comes first. This suggests that the students with high self-efficacy level have higher intrinsic motivation. Yet another outcome achieved in the study is that extrinsic motivation and academic achievement predict students' self-efficacy. Dağlığulu, Genç, Yüksek Usta [32] found out that there is a positive relationship between self-efficacy and extrinsic motivation in the study they conducted. Yet Gottfried [33], Walker, Greene and Mansell [29] achieved similar results between self-efficacy and extrinsic motivation. In many studies on self-efficacy belief, it was determined that there is a positive relationship between academic achievement and self-efficacy belief. The result of this study is similar to the results of studies revealing positive correlation between academic achievement and self-efficacy [20,34,35,36,37,38,39,40]. Self-efficacy is one of the main factors affecting student achievement positively. For this reason, it should not be forgotten that it is necessary to increase the self-sufficiency levels in order to increase the success of the students within the social studies course. The most important task at this point is on teachers. Teachers should consider the activities that will increase the self-efficacy levels of the students as well as the teaching practices that will make students successful, and they should teach their lessons accordingly.

\section{REFERENCES}

[1] Akbaba, S. (2006). Eğitimde motivasyon. Kazım Karabekir Ĕgitim Fakültesi Dergisi, 13, 342-361.

[2] TDK,http://www.tdk.gov.tr/index.php?option=com_gts\&ar ama=gts\&guid=TDK.GTS.5afd2960ebc7d7.84832368adre sinden, 14.04.2018 tarihinde alınmıştır.

[3] Ryan, R. M. \& Deci, E. L. (2000). Intrinsic and extrinsic motivations: Classic definitions and new directions. Contemporary Educational Psychology, 25, 54-67.

[4] Pintrich, P. R. \& Schunk, D. H. (2002). Motivation in education: theory, research, and application. (2nd, Ed.). New Jersey: Merrill Prentice Hall.

[5] Deci, E. L. \& Ryan, R. M. (1985). Intrinsic motivations and self-determinetion in human behavior. New York: Plenum Publishing Co. Chen, A. (2001). A theoretical conceptualization for motivation research in physical education: An integrated perspective. Quest, 2, 35-58.

[6] Gürşimşek, I. (2002). Öğretmen adaylarında öğrenmeye iliş̧in motivasyonel inançlar ve strateji kullanımı. Muğla Universitesi Sosyal Bilimler Enstitüsü Dergisi, 8

[7] Altun, F. ve Yazıcı, H. (2010). Öğrencilerin Okul Motivasyonunu Yordayan Bazı Değişkenler, International Conference on New Trends in Education and their Implications, (11-13 November), Antalya-Turkey.

[8] Von Glasersfeld, E. (1998). Cognition, construction of knowledge and teaching. In M.R. Matthews (Ed.) Constructivism in Science Education (11-30). Dordrecht: Kluwer Academic.

[9] Schunk, D. H. (2011). Öğrenme teorileri: eğitimsel bir bakış. (Çeviri Editörü: Muzaffer Şahin). 2. Baskı, Ankara: Nobel Yayıncilik. 
[10] Kelecioğlu, H. (1992). Güdülenme. Hacettepe Üniversitesi Eğitim Fakültesi Dergisi, 7(7). 175-181.

[11] Sarıtepeci M. ve Çakır, H. (2014). Harmanlanmış öğrenmenin öğrencilerin sosyal bilgiler dersine yönelik motivasyon ve tutumlarına etkisinin incelenmesi. Pamukkale Üniversitesi Eğitim Fakültesi Dergisi, 35(1), 115-129.

[12] Karataş, H. ve Erden, M. (2012). Akademik motivasyon ölçeğinin dilsel eşdeğerlik, geçerlik ve güvenirlik çalişmasi. e-Journal of New World Sciences Academy, 7(4), 983-1003.

[13] Garcia, T. (1995). The role of motivational strategies in self-regulated learning. New Directions for Teaching and Learning, 63, 29-42.

[14] Bandura, A. (1997). Self efficacy: the exercise of control,. New York: W. H. Freeman and Company.

[15] Bandura, A. (1995). Exercise of personal and collective efficacy in changing societies. In A. Bandura (Ed.), Self-efficacy in changing societies (pp. 1-45). New York: Cambridge University Press.

[16] Aydın, S. ve Demir Atalay, T. (2014). Öz-düzenlemeli ögrenme. Pegem Akademi, Ankara.

[17] Sewell, A., \& St George, A. (2000). Developing efficacy beliefs in the classroom. Journal of Educational Enquiry, $1(2), 58-71$.

[18] Doğan, N., İlhan Beyaztaş, D. ve Koçak, Z. (2012). Sosyal bilgiler dersine ilişkin özyeterlik düzeyinin başarıya etkisinin sınıf ve cinsiyete göre incelenmesi: Erzurum İli örneği, Ĕgitim ve Bilim, 37, 165, 224-236.

[19] Schunk D. H. (1996). Goal and self-evaluative influences during children's cognitive skill learning. American Educational Research Journal, 33, 359-382.

[20] Özkal, N. (2013). Sosyal bilgilere ilişkin içsel ve dişsal güdülerin özyeterlik ve başarı yönelimlerine göre yordanması. Mehmet Akif Ersoy Üniversitesi Ĕ̆itim Fakültesi Dergisi, 13, 27, 98 - 117.

[21] Jöreskog, K. G., \& Sörbom, D. (2006). LISREL 8.80 for Windows [Computer Software]. Lincolnwood, IL: Scientific Software International, Inc.

[22] Gömleksiz, M. N. ve Kan, A. (2012). Sosyal bilgiler dersi motivasyon ölçeğinin geçerlik ve güvenirlik çalışması, Firat Üniversitesi Sosyal Bilimler Dergisi, 22 (2), 116-125.

[23] Eggen, P., \& Kauchak, P. D. (1997). Educational psychology, New Jersey: PrenticeHall. Inc.

[24] Bandura, A. (2001). Social cognitive theory: an agentic perspective. Annual Review of Psychology, 52, 1-26.

[25] Sezgin Saf, A. (2011). Ortaöğretim 9. sinif öğrencilerinin kimya dersine ilişkin tutum, motivasyon ve öz yeterlik algilarinin çeșitli değișkenler ile incelenmesi. Yayınlanmamış Yüksek Lisans Tezi, Selçuk Üniversitesi, Eğitim Bilimleri Enstitüsü.

[26] Çetin Dindar, A. ve Geban, Ö. (2015). Fen bilimleri motivasyon ölçeğinin türkçe'ye ve kimya'ya uyarlanmasi: geçerlilik çalişmasi. Pegem Ĕ̆itim ve Öğretim Dergisi, 5(1), $15-34$.

[27] Viau, R. (2015). Okulda motivasyon: okulda güdülenme ve güdülenmeyi ögrenme. Ankara: Anı Yayınc1l1k.

[28] Deci, E. L., Vallerand, R. J., Pelletier, L. G. \& Ryan, R. M. (1991). Motivation and education: The self-determination perspective. Educational Psychologist, 26, 325-346.

[29] Walker, C. O., Greene, B. A., \& Mansell, R. A. (2006). Identification with academics, intrinsic/extrinsic motivation, and self-efficacy as predictors of cognitive engagement. Learning and Individual Differences, 16(1), $1-12$.

[30] Yıldırım, S. (2011). Öz-yeterlik, içe yönelik motivasyon, kayg1 ve matematik başarısı: Türkiye, Japonya ve Finlandiya'dan bulgular. Necatibey Ĕgitim Fakültesi Elektronik Fen ve Matematik Eğitimi Dergisi, 5(1), 277-291.

[31] Aydin, S. (2016). An analysis of the relationship between high school students' self-efficacy, metacognitive strategy use and their academic motivation for learn biology. Journal of Education and Training Studies, 4(2), 53-59.

[32] Dağlığlu, H. E., Genç, H. ve Yüksek Usta, S. (2017). Okul öncesi öğretmen adaylarinin akdemik motivasyonlari ile matematik öğretimine ilişkin özyeterlik inançlari arasindaki ilisskinin incelenmesi. Turkish Studies, 12(6), $235-260$

[33] Gottfried, A. E. (1985). Akademic intrinsic motivation in elementary and junior high school students. Journal of Educational Psychology, 77 (6), 631-645.

[34] Schunk, D. H. (1989). Self-efficacy and achievement behaviors. Educational Psychology Review, 1, 173-207.

[35] Bandura, A., Barbaranelli, C., Caprara, G.V., ve Pastorelli, C. (1996). Multifaceted impact of self-efficacy beliefs on academic functioning. Child development, 67 (3), 12061222.

[36] Pajares, F. (1996). Self-efficacy beliefs in academic settings. Review of educational research, 66(4), 543-578.

[37] Zimmerman, B. J. \& Kitsantas, A. (2005). Students' perceived responsibility and completion of homework: The role of self-regulatory beliefs and processes. Contemporary educational psychology, 397-417

[38] Zajacova, A., Lynch, S. M. \& Espenshade, T.J. (2005). Self-efficacy, stress, and academic success in college. Research in HigherEducation, 46 (6), 677-706.

[39] Long, J. F., Monoi, S., Harper, B., Knoblauch, D., \& Murphy, P. K. (2007). Academic motivation and achievement among urban adolescents. Urban Education, 42(3), 196-222.

[40] Coutinho, S. A. \& Neuman, G. (2008). A model of metacognition, achievement goal orientation, learning style and self-efficacy. Learning Environments Research, 11(2), 131-151. 